\title{
Editorial \\ Closing Biogeochemical Cycles and Meeting Plant Requirements by Smart Fertilizers and Innovative Organic Amendments
}

\author{
María de la Luz Mora ${ }^{1}\left(\mathbb{D}\right.$, Marcela Calabi-Floody ${ }^{1,2, *}$ and Cornelia Rumpel ${ }^{1,3, *}$ \\ 1 Center of Plant, Soil Interaction and Natural Resources Biotechnology, Scientific and Biotechnological \\ Bioresource Nucleus, Universidad de La Frontera, BIOREN-UFRO, Av. Francisco Salazar, \\ Temuco 01145, Chile; mariluz.mora@ufrontera.cl \\ 2 Nano-Biotechnology Laboratory, Universidad de La Frontera, Temuco 4811230, Chile \\ 3 Institute of Ecology and Environmental Sciences, UMR 7618 (CNRS, Sorbonne U, UPEC, INRAE, IRD), \\ 75005 Paris, France \\ * Correspondence: marcela.calabi@ufrontera.cl (M.C.-F.); cornelia.rumpel@inrae.fr (C.R.)
}

Citation: Mora, M.d.l.L.; Calabi-Floody, M.; Rumpel, C. Closing Biogeochemical Cycles and Meeting Plant Requirements by Smart Fertilizers and Innovative Organic Amendments. Agronomy 2021, 11, 1158. https://doi.org/ 10.3390/agronomy11061158

Received: 29 April 2021

Accepted: 3 June 2021

Published: 5 June 2021

Publisher's Note: MDPI stays neutral with regard to jurisdictional claims in published maps and institutional affiliations.

Copyright: (c) 2021 by the authors. Licensee MDPI, Basel, Switzerland. This article is an open access article distributed under the terms and conditions of the Creative Commons Attribution (CC BY) license (https:// creativecommons.org/licenses/by/ $4.0 /)$.

\section{Meeting the Growing Food Demand of the Global Population: Challenges for Sustainable Agriculture}

Expansion of farmland with food production as a major service has been largely associated with conversion of natural ecosystems like the Amazon and Savanna into new agricultural land [1]. It has resulted in the large scale modification of natural landscapes and ecosystems, altering important climate interactions, such as surface moisture and microbial diversity, and strongly impacting greenhouse gas (GHG) emissions [2]. Indeed, current agricultural activities are the main contributors to GHG emissions, representing globally $20 \%$ of the annual atmospheric emissions [3]. They are largely driven by land use change and decoupling of biogeochemical cycles leading to land degradation, and soil organic matter loss since the introduction of agriculture [2,4]. Agriculture contributes to GHG emissions by releasing $\mathrm{CO}_{2}, \mathrm{~N}_{2} \mathrm{O}$ and $\mathrm{CH}_{4}$. The agricultural sector is the main contributor to $\mathrm{N}_{2} \mathrm{O}$ and $\mathrm{CH}_{4}$ emissions, which have 260 and 40 times greater global warming potential than $\mathrm{CO}_{2}$. In particular, $\mathrm{N}$ fertilizers are important $\mathrm{N}_{2} \mathrm{O}$ sources. Nowadays, it has become clear that agriculture is not only causing climate change by GHG emission, but that it is also highly vulnerable to climate change, which is threatening crop yields in many parts of the world [5]. Moreover, the green revolution in the 1960s, which strongly reformed and increased agricultural production, also had many adverse effects on the environment [6], including soil acidification and pollution of waterways through export of mineral fertilizers not taken up by plants $[7,8]$. The use of agrochemicals to fight weeds and pests led to biodiversity loss, and highlighted the need for an agroecological transition and a second green revolution. An additional challenge is the necessity to achieve food security of a growing global population [9].

As the earth surface covered by agricultural land (more than $40 \%$ of the total Earth surface) cannot be expended anymore [2], sustainable intensification of production on the existing area, while reducing mineral agrochemical use and adapting to climate change, is a great challenge for landowners, scientists and politicians. Recently, it has been suggested that increasing carbon storage in soils could be a solution to mitigate and to adapt to climate change while at the same time supporting agricultural production to increase food security $[10,11]$. Such a solution can only be brought to scale if region specific solutions adapted to pedoclimatic and socioeconomic conditions are employed [12]. One aspect of sustainable solutions is the replacement of mineral fertilizers by innovative strategies to enhance plant growth. In the light of circular economy, it was suggested that smart fertilization strategies could be based on the transformation of organic wastes from agricultural systems into innovative organic amendments $[13,14]$ and/or carrier materials 
for beneficial microorganisms and/or enzymes [15]. While improving nutrient availability, fertilization strategies based on organic materials may be an avenue towards sustainable intensification.

Therefore, it is imperative to concentrate efforts to develop innovative fertilizers through biotechnological approaches with or without use of beneficial microorganisms that allow their viability in the soil in the face of an established microbiome. Innovative organic amendments with low GHG emission potential should be designed to foster terrestrial C sequestration and stabilization, capable of mitigating the environmental impact caused by the agricultural sector, while at the same time increasing soil health and adapting to climate change. For this Special Issue, we invited contributions dealing with innovations in organic and inorganic fertilization strategies in order to improve agricultural yields, while at the same time reducing negative externalities and increasing the soils' organic matter contents. It contains 11 articles reporting (1) the effects of new fertilization strategies on soils and plants, (2) characteristics of innovative organic amendments and (3) system innovations based on organic fertilization and waste recycling.

\section{Smart Fertilizer Development and Their Effect on Soils and Plants}

As the main limiting factor for food production is $\mathrm{N}$ and $\mathrm{P}$ availability, huge amounts of conventional $\mathrm{N}$ and P-fertilizer are applied per year, which often lead to environmental damage [16]. Especially N-fertilizer application at levels exceeding plant requirements leads to significant environmental consequences due to $\mathrm{N}$ losses, such as: nitrate $\left(\mathrm{NO}_{3}{ }^{-}\right)$ leaching, ammonia $\left(\mathrm{NH}_{3}\right)$ volatilization, and nitrous oxide $\left(\mathrm{N}_{2} \mathrm{O}\right)$ emission [8,17-19]. The $\mathrm{N}$ losses by urea application is one of the main problems in agricultural systems, where leaching of $\mathrm{NO}_{3}{ }^{-}$is one of the most important loss pathways due to its high mobility [20]. Incrocci et al. [21] used a (bio)technological approach to develop an innovative controlledrelease polyurethane-coated urea fertilizer, which could considerably reduce the $\mathrm{N}$ leaching in tomato cultivations. Unlike $\mathrm{N}$, phosphorus $(\mathrm{P})$ is mainly fixed in the soil systems. Therefore, the efforts to improve $\mathrm{P}$ use efficiency are focusing on favoring slow release and preventing P fixation in the soil. In this context, Shafi et al. [22] reported that the incorporation of humic acid in combination with chemical P fertilizer can prevent the $P$ fixation in calcareous soil, thus improving crop yield and wheat (Triticum aestivum L.) plants' P uptake. Teles et al. [23] developed a new P fertilizer with slow solubility through the partial acidification of rock phosphates, incorporating zeolite and pillared clay into partially acidulated phosphates with high adsorption characteristics. The mechanism of $\mathrm{P}$ release is based on the saturation the acidic sites of the clay materials before adsorption. These saturated sites may act as a vehicle for slow and gradual dissolution into soil solution. This strategy seems to be highly promising as it was able to compete with conventional fertilizers.

Mineral fertilization may also lead to soil acidification thereby increasing aluminum $\left(\mathrm{Al}^{3+}\right)$ toxicity $[7,24,25]$. In this context, Vega et al. [26] studied the beneficial effects of silicon application for mitigating $\mathrm{Al}^{3+}$ toxicity in sensitive barley cultivars. Their findings revealed that silicon fertilization could increase the resistance of barley to $\mathrm{Al}^{3+}$ toxicity by regulating the metabolism of phenolic compounds with antioxidant and structural functions.

A liquid biofertilizer combined with a microbial consortium was evaluated by Yousef et al. [27]. These authors used a bacteria and fungi consortium containing Bacillus circulans, B. poylmyxa, B. megatherium, Candida spp., and Trichoderma spp. and studied its combined effect with liquid biofertilizer on Jew's mallow plant production. They concluded that combined application of inorganic NPK plus biofertilizer is most beneficial to increase growth, yield, and nutrient accumulation of Jew's mallow plants.

\section{Innovative Organic Amendments}

In order to move to carbon neutrality in agricultural production in agreement with sustainable development goals and global governmental treaties to minimize climate 
change, different initiatives were launched, such as " 4 per Thousand (4p1000)" at the COP21 in Paris, or the Agenda 2030 of the United Nations [28]. Recently, FAO and the Global Soil Partnership (GSP) established "RECSOIL: Recarbonization of global soils" as an initiative to implement the soil organic carbon (SOC) agenda by using the best tools and technologies available [29]. Organic amendments may be a keystone to increase SOC sequestration and provide food security through soil quality improvement. Reuse of organic waste and their transformation into organic amendments is a sustainable strategy that farmers need to apply and scientists have the challenge to innovate. In this context, Emadodin et al. [30] proposed jellyfish application as an organic soil amendment able to allow enhanced seedling growth and establishment of ryegrass on sand dune soil even under water scarcity conditions.

Under a circular economy approach, black soldier flies have the capacity to transform anthropogenic organic wastes into nutritious insect biomass (frass). The fertilizer potential of frass was studied by Klammsteiner et al. [31], who reported that it may serve as a valuable alternative to mineral fertilizers with beneficial effects on plant growth and not impairing the hygienic properties of soils. In addition, Dulaurent et al. [32] investigated the effect of earthworms (Lumbricus terrestris L.) on nutrient uptake and crop growth in the presence of frass from mealworm (Tenebrio molitor L.). Their study showed a synergistic effect between earthworms and frass on soil fertility and that earthworms thus may improve the efficiency of frass as an organic fertilizer.

Composting, vermicomposting and biochar production using organic wastes are known sustainable practices, which convert these raw materials into valuable organic amendments. Organic amendments may be used individually or in mixture to improve soil carbon sequestration and fertility at the same time [13,33,34]. Aubertin et al. [35] addressed the effect of weathering on biochar-compost mixture properties, their biological stability and their effect on plant growth after soil addition. They were able to show that weathering changed synergistic effects of biochar compost mixtures in terms of carbon sequestration potential and biomass production.

\section{System Innovations Based on Organic Fertilization and Waste Recycling}

Finally, in order to integrate sustainable agricultural practices, system innovations based on agroecological approaches and waste recycling must be employed. In this context, use of legumes as cover crops in agricultural rotations may reduce the production costs associated with the use of mineral $\mathrm{N}$ fertilizers, and also result in environmental benefits. In order to optimize biomass productivity, biological nitrogen fixation, and transpiration efficiency, Berriel et al. [36] evaluated the application of two Crotalaria species, specifically C. juncea and C. spectabilis grown under extreme environmental conditions with the finality to maximize their beneficial attributes, while minimizing water consumption through high transpiration. Their results showed that the $C$. spectabilis has advantages as legumes cover crop over C. juncea, in terms of transpiration as indicated by a ${ }^{13} \mathrm{C}$ isotopic analyses.

On the other hand, the chemical fertilizers dependence and/or its coming shortage is a global concern and a huge challenge in terms of food security [15,37]. Thus, the circular economy approach suggests that agricultural systems must become more efficient and favor reuse of their waste as fertilizers in order to reduce external inputs. In this context, recycling of fishpond sediments may be an alternative to reduce the reliance on synthetic fertilizers, due to its high nutritional value [38]. Da et al. [39] studied organic fertilizers based on a composted mixture of $30 \%$ of the Pangasius catfish pond sediment and $70 \%$ of agricultural waste in cucumber vegetable production. With this strategy, they reduced mineral fertilizer use by up to $75 \%$. Therefore, their results provide evidence that systeminherent organic amendments can be integrated in fish-vegetable farming to provide a more diversified production system with tangible environmental benefits and potentially improved farm income.

The papers presented in this Special Issue indicate that there are multiple ways to increase the production efficiency of agriculture and to reduce external inputs using smart 
fertizers and innovative organic amendments. We suggest that such strategies should be scaled up to achieve sustainability in agriculture through waste recycling aiming a circular approach to close biogeochemical cycles.

Funding: The authors thank the Chilean government for providing a MEC grant $\mathrm{N}^{\circ}$ MEC 80180025 . M.C.F. acknowledges funding from Chilean CONICYT (National foundation for Science and Technology) for the financial support under CONICYT-FONDECYT Regural project $\mathrm{N}^{\circ} 1201375$, and M.L.M. thanks FONDECYT Regular N ${ }^{\circ} 1181050$. We also acknowledge ECOSSUD-CONICYT C13U02 for their financial support to encourage collaboration between French and Chilean research groups.

Data Availability Statement: Not applicable.

Acknowledgments: This Special Issue was launched during the sabbatical of C.R. at the Universidad de la Frontera (Temuco, Chile).

Conflicts of Interest: The authors declare no conflict of interest.

\section{References}

1. Campbell, B.M.; Beare, D.J.; Bennett, E.M.; Hall-Spencer, J.M.; Ingram, J.S.I.; Jaramillo, F.; Ortiz, R.; Ramankutty, N.; Sayer, J.A.; Shindell, D. Agriculture production as a major driver of the Earth system exceeding planetary boundaries. Ecol. Soc. 2017, 22. [CrossRef]

2. McDermid, S.S.; Mearns, L.O.; Ruane, A.C. Representing agriculture in Earth System Models: Approaches and priorities for development. J. Adv. Model. Earth Syst. 2017, 9, 2230-2265. [CrossRef] [PubMed]

3. IPCC. Global Warming of 1.5 C. 2018. Available online: https://ipcc.ch/report/sr15/ (accessed on 22 May 2021).

4. Sanderman, J.; Hengl, T.; Fiske, G.J. Soil carbon debt of 12,000 years of human land use. Proc. Natl. Acad. Sci. USA 2017, 114, 9575-9580. [CrossRef]

5. Ray, D.K.; Ramankutty, N.; Mueller, N.D.; West, P.C.; Foley, J.A. Recent patterns of crop yield growth and stagnation. Nat. Commun. 2012, 3, 1293. [CrossRef]

6. Pingali, P.L. Green revolution: Impacts, limits, and the path ahead. Proc. Natl. Acad. Sci. USA 2012, 109, 12-302. [CrossRef] [PubMed]

7. Mora, M.D.L.L.; Cartes, P.; Núñez, P.; Salazar, M.; Demanet, R. Movement of n0(3)-n and nh4-n in an andisol and its influence on ryegrass production in a short term study. Rev. Cienc. Suelo Y Nutr. Veg. 2007, 7, 46-64. [CrossRef]

8. Good, A.G.; Beatty, P.H. Fertilizing Nature: A Tragedy of Excess in the Commons. PLoS Biol. 2011, 9, e1001124. [CrossRef]

9. Poppy, G.M.; Jepson, P.C.; Pickett, J.A.; Birkett, M.A. Achieving food and environmental security: New approaches to close the gap. Phil. Trans. R. Soc. B 2014, 369, 20120272. [CrossRef] [PubMed]

10. Chabbi, A.; Lehmann, J.; Ciais, P.; Loescher, H.W.; Cotrufo, M.F.; Don, A.; SanClements, M.; Schipper, L.; Six, J.; Smith, P.; et al. Aligning agriculture and climate policy. Nat. Clim. Chang. 2017, 7, 307-309. [CrossRef]

11. Rumpel, C.; Amiraslani, F.; Chenu, C.; Cardenas, M.G.; Kaonga, M.; Koutika, L.-S.; Ladha, J.; Madari, B.; Shirato, Y.; Smith, P.; et al. The 4p1000 Initiative: Opportunities, limitations and challenges for implementing soil organic carbon sequestration as a sustainable development strategy. Ambio 2020, 49, 350-360. [CrossRef] [PubMed]

12. Amelung, W.; Bossio, D.; de Vries, W.; Kögel-Knabner, I.; Lehmann, J.; Amundson, R.; Bol, R.; Collins, C.; Lal, R.; Leifeld, J.; et al. Towards a global-scale soil climate mitigation strategy. Nat. Commun. 2020, 11, 5427. [CrossRef]

13. Barthod, J.; Rumpel, C.; Dignac, M.-F. Composting with additives to improve organic amendments. A review. Agron. Sustain. Dev. 2018, 38, 17. [CrossRef]

14. Zhao, S.; Schmidt, S.; Qin, W.; Li, J.; Li, G.; Zhang, W. Towards the circular nitrogen economy-A global meta-analysis of composting technologies reveals much potential for mitigating nitrogen losses. Sci. Total. Environ. 2020, 704, 135401. [CrossRef]

15. Calabi-Floody, M.; Medina, J.; Rumpel, C.; Condron, L.M.; Hernandez, M.; Dumont, M.; Mora, M.L. 2018. Chapter Three - Smart fertilizers as a strategy for sustainable agriculture. In: Donald LS, editor. Adv. Agron. 2018, 147, 119-157. [CrossRef]

16. Roy, R.N.; Finck, A.; Blair, G.J.; Tandon, H.L.S. Plant nutrition for food security. In A Guide for Integrated Nutrient Management; FAO Fertilizer and Plant Nutrition Bulletin: Rome, Italy, 2006; Volume 16.

17. Muñoz, C.; Paulino, L.; Monreal, C.; Zagal, E. Greenhouse Gas (CO2 AND N2O) Emissions from Soils: A Review. Chil. J. Agric. Res. 2010, 70, 485-497. [CrossRef]

18. Núñez, P.A.; Demanet, R.; Misselbrook, T.H.; Alfaro, M.; Mora, M.D.L.L. Nitrogen Losses under Different Cattle Grazing Frequencies and Intensities in a Volcanic Soil of Southern Chile. Chil. J. Agric. Res. 2010, 70, 237-250. [CrossRef]

19. Saggar, S.; Jha, N.; Deslippe, J.; Bolan, N.; Luo, J.; Giltrap, D.; Kim, D.-G.; Zaman, M.; Tillman, R. Denitrification and N2O:N2 production in temperate grasslands: Processes, measurements, modelling and mitigating negative impacts. Sci. Total. Environ. 2013, 465, 173-195. [CrossRef] [PubMed]

20. Omar, L.; Ahmed, O.H.; Majid, N.M.A. Improving Ammonium and Nitrate Release from Urea Using Clinoptilolite Zeolite and Compost Produced from Agricultural Wastes. Sci. World J. 2015, 2015, 1-12. [CrossRef] 
21. Incrocci, L.; Maggini, R.; Cei, T.; Carmassi, G.; Botrini, L.; Filippi, F.; Clemens, R.; Terrones, C.; Pardossi, A. Innovative ControlledRelease Polyurethane-Coated Urea Could Reduce N Leaching in Tomato Crop in Comparison to Conventional and Stabilized Fertilizers. Agronomy 2020, 10, 1827. [CrossRef]

22. Shafi, M.I.; Adnan, M.; Fahad, S.; Wahid, F.; Khan, A.; Yue, Z.; Danish, S.; Zafar-Ul-Hye, M.; Brtnicky, M.; Datta, R. Application of Single Superphosphate with Humic Acid Improves the Growth, Yield and Phosphorus Uptake of Wheat (Triticum aestivum L.) in Calcareous Soil. Agronomy 2020, 10, 1224. [CrossRef]

23. Teles, A.P.B.; Rodrigues, M.; Pavinato, P.S. Solubility and Efficiency of Rock Phosphate Fertilizers Partially Acidulated with Zeolite and Pillared Clay as Additives. Agronomy 2020, 10, 918. [CrossRef]

24. Haygarth, P.M.; Bardgett, R.D.; Condron, L.M. Phosphorus and nitrogen cycles and their management. In Soil Conditions and Plant Growth; Gregory, P.J., Nortcliff, S., Eds.; Wiley-Blackwell: Hoboken, NJ, USA, 2013; pp. 132-159.

25. Mora, M.L.; Demanet, R.; Vistoso, E.; Gallardo, F. Influence of Sulfate Concentration in Mineral Solution on Ryegrass Grown at different $\mathrm{pH}$ and aluminium levels. J. Plant Nutr. 2005, 28, 1-16. [CrossRef]

26. Vega, I.; Rumpel, C.; Ruíz, A.; Mora, M.D.L.L.; Calderini, D.F.; Cartes, P. Silicon Modulates the Production and Composition of Phenols in Barley under Aluminum Stress. Agronomy 2020, 10, 1138. [CrossRef]

27. Yousef, A.F.; Youssef, M.A.; Ali, M.M.; Ibrahim, M.M.; Xu, Y.; Mauro, R.P. Improved Growth and Yield Response of Jew's Mallow (Corchorus olitorius L.) Plants Through Biofertilization Under Semi-Arid Climate Conditions in Egypt. Agronomy 2020, 10, 1801. [CrossRef]

28. Lal, R. Food security impacts of the "4 per Thousand" initiative. Geoderma 2020, 374, 114427. [CrossRef]

29. FAO. "RECSOIL: Recarbonization of Global Soils" a Tool to Support the Implementation of the Koronivia Joint Work on Agriculture; FAO: Rome, Italy, 2019.

30. Emadodin, I.; Reinsch, T.; Ockens, R.-R.; Taube, F. Assessing the Potential of Jellyfish as an Organic Soil Amendment to Enhance Seed Germination and Seedling Establishment in Sand Dune Restoration. Agronomy 2020, 10, 863. [CrossRef]

31. Klammsteiner, T.; Turan, V.; Juárez, M.F.-D.; Oberegger, S.; Insam, H. Suitability of Black Soldier Fly Frass as Soil Amendment and Implication for Organic Waste Hygienization. Agronomy 2020, 10, 1578. [CrossRef]

32. Dulaurent, A.-M.; Daoulas, G.; Faucon, M.-P.; Houben, D. Earthworms (Lumbricus terrestris L.) Mediate the Fertilizing Effect of Frass. Agronomy 2020, 10, 783. [CrossRef]

33. Agegnehu, G.; Bird, M.I.; Nelson, P.; Bass, A.M. The ameliorating effects of biochar and compost on soil quality and plant growth on a Ferralsol. Soil Res. 2015, 53, 1-12. [CrossRef]

34. Scotti, R.; Conte, P.; Berns, A.; Alonzo, G.; Rao, M.A. Effect of Organic Amendments on the Evolution of Soil Organic Matter in Soils Stressed by Intensive Agricultural Practices. Curr. Org. Chem. 2013, 17, 2998-3005. [CrossRef]

35. Aubertin, M.-L.; Girardin, C.; Houot, S.; Nobile, C.; Houben, D.; Bena, S.; Brech, Y.; Rumpel, C. Biochar-Compost Interactions as Affected by Weathering: Effects on Biological Stability and Plant Growth. Agronomy 2021, 11, 336. [CrossRef]

36. Berriel, V.; Monza, J.; Perdomo, C. Cover Crop Selection by Jointly Optimizing Biomass Productivity, Biological Nitrogen Fixation, and Transpiration Efficiency: Application to Two Crotalaria Species. Agronomy 2020, 10, 1116. [CrossRef]

37. Cordell, D.; Drangert, J.-O.; White, S. The story of phosphorus: Global food security and food for thought. Glob. Environ. Chang. 2009, 19, 292-305. [CrossRef]

38. Muendo, P.N.; Verdegem, M.C.J.; Stoorvogel, J.J.; Milstein, A.; Gamal, E.; Duc, P.M.; Verreth, J.A.J. Sediment accumulation in fish ponds: Its potential for agricultural use. Int. J. Fisher. Aquat. Stud. 2014, 1, 228-241.

39. Da, C.T.; Tu, P.A.; Livsey, J.; Tang, V.T.; Berg, H.; Manzoni, S. Improving Productivity in Integrated Fish-Vegetable Farming Systems with Recycled Fish Pond Sediments. Agronomy 2020, 10, 1025. [CrossRef] 